\title{
Revenue Intensification to Improve Financial Strength of Medan City: A SWOT Analysis
}

\author{
Khaira Amalia Fachrudin 1*, Muhammad Rifky Santoso², Elisabet Siahaan1, \\ Hilma Tamiami Fachrudin 3 , Imam Faisal Pane ${ }^{3}$ \\ ${ }^{1}$ Faculty of Economic and Business, Universitas Sumatera Utara, Medan, Indonesia \\ ${ }^{2}$ Widyaiswara, Finance Education Training Agency, Ministry of Finance, Medan, Indonesia \\ ${ }^{3}$ Faculty of Engineering, Universitas Sumatera Utara, Medan, Indonesia \\ Email: *khaira@usu.ac.id
}

How to cite this paper: Fachrudin, K.A., Santoso, M.R., Siahaan, E., Fachrudin, H.T. and Pane, I.F. (2019) Revenue Intensification to Improve Financial Strength of Medan City: A SWOT Analysis. Open Journal of Business and Management, 7, 386-395. https://doi.org/10.4236/ojbm.2019.72026

Received: January 10, 2019

Accepted: February 12, 2019

Published: February 15, 2019

Copyright (C) 2019 by author(s) and Scientific Research Publishing Inc. This work is licensed under the Creative Commons Attribution International License (CC BY 4.0).

http://creativecommons.org/licenses/by/4.0/

\begin{abstract}
A financial strength is a very important factor for a local government because it can support the government function, providing goods and services to the society. The main sources of the financing are tax revenues from hotels, restaurants, entertainments, and parking. There are some obstacles to collect these taxes with the self-assessment system because the taxpayers are reluctant to report the actual income. Besides these tax revenues, the property tax, such as land and building taxes have some problems for collecting. This paper proposes the intensification strategy by using SWOT analysis to strength Medan City's financing. A semi-structured interviewing is conducted to respondents, such as local tax officers, central tax officers, tax lecturers, and taxpayers to collect data and information about strengths, weaknesses, opportunities, and threats. After making SWOT analysis, the results are discussed with the respondents. This paper proposes 12 strategies to increase property tax and 17 strategies to increase tax revenues from hotels, restaurants, entertainments, and parking. These strategies generate 5 policies to monitor, update data, increase human resources, counsel and socialize, improve coordinating, and cooperate with other units.
\end{abstract}

\section{Keywords}

Financial Strength, Revenue Intensification, SWOT Analysis

\section{Introduction}

Financial strength lies in the ability to generate revenues [1]. The financial strength for the regional government can provide enough services to the society, like public goods and services. Government financial power would be obtained if 
individuals and organizations fulfill their tax obligations [2].

Medan City is the capital of North Sumatera Province, Indonesia. Medan City is the third largest metropolitan city in Indonesia and the largest metropolitan city outside Java Island. Tax and Retribution Management Agency (BPRRD) in Medan City still has problems in the tax management related to manage tax revenues, such as tax and data collection from taxpayers. Collection of receivables will increase cash flow and will increase value [3]. The tax revenues importantly increase the financial strength; therefore, the strengthening of management function is needed. There are four management functions, planning, organizing, leading, and controlling [4].

The Law of Republic Indonesia number 12 of year 2008 concerning Regional Government states that the regional government has an authority to manage its territory and this regional autonomy part of the unity of the state administration system. To support the autonomy, the Law of Republic Indonesia number 28 year 2009 concerning Regional Tax and Regional Retribution gives the regional to receive property tax as revenues. Besides the property tax, the Acquisition Duty, former as state tax, is to be the local tax and supports the regional financing. This fact creates some problems for the local government, such as Medan City. Medan City has difficulties to identify the data changing and to value the tax objects.

The government of Medan City has increased or revaluated the value of the land and building as based to impose property tax (NJOP) since 2014. This revaluation is consistent with Loan and McCuskey [5] that explains the based of the property tax should reflect the land actual values. The property tax is calculated by multiplying the NJOP by the tax rate. This new calculation has increased the property tax payable. Consequently, most of the taxpayers are reluctant to pay the property tax. This new formula or calculation is still a society's question because the calculation is not fair.

Property tax is the main source of Medan City's revenues. This fact is consistent with Babawale [6] that states property tax has played a significant role in financing local authorities in the several developed countries. The next significant revenues of Medan City are tax revenues from hotels, restaurants, entertainments, and parking that using self-assessment system for collecting. One main requirement in applying self-assessment system is the availability of supporting data. Medan City has problems in gathering this data and has limitation to confirm the correctness of tax paid and reported. The government estimates that there is a lot of tax revenues potency in its territory although the tax revenues targets are reached.

The self assessment system enforces greater accountability in terms of computational, recordkeeping and filing requirements upon taxpayers [7]. Tax compliance costs can be reduced by the simplification of tax legislation and reporting requirements, convergence of tax law with accounting standards and practices, technical training and internal staff development, audits and investigations processes.

The tax regulations have stated that the government has an authority to verify 
and to audit taxpayers to confirm the correctness of tax payments. The tax audits have direct and indirect effect to taxpayers' complying [8] [9]. The direct effect can increase the tax revenues. The indirect effect can generate the deterrence effect, where a tax audit is considered to deter potential tax evaders. However, there are still some collusive officers with taxpayers in conducting tax audits, consequently, the tax revenues received are lower than that of expected. The taxpayers who avoid taxes often make bribes and the tax officers who accept the bribes will hide the receipt illegally [10].

From the facts, the formulation of the problem in this paper is the tax revenues collection still under the tax revenues potency. The purpose of this paper is to formulate tax intensification strategy and policies to increase tax revenues and to minimize the existing problems. This paper finds that Medan City needs to use tapping device, improve the human resources capacities especially in asset revaluation and tax audit, counsel and socialize tax payers, and coordinating with other related agencies.

\section{Method}

Semi-structured interviews are conducted to explore and collect the respondents' opinions about strengths, weaknesses, opportunities, and threats in collecting tax revenues in Medan City's territory. Table 1 describes respondents and questions for them.

This study uses descriptive analysis and SWOT analysis to generate strategies. The strategies are discussed in the Focus Group Discussion (FGD) with the respondents that determined by purposively who understand about self-assessment system.

\section{Results and Discussion}

The results of this paper are divided in to:

Table 1. Respondents and questions.

\begin{tabular}{|c|c|c|c|}
\hline No. & Personal Number & Position/Work & Questions \\
\hline 1 & 1 person & $\begin{array}{l}\text { The Chief of officers in the Tax and } \\
\text { Distribution Management Agency }\end{array}$ & $\begin{array}{l}\text { Strengths, weaknesses, opportunities, } \\
\text { and threats in collecting retribution } \\
\text { and tax revenues. }\end{array}$ \\
\hline 2 & 4 persons & $\begin{array}{l}\text { Head of the departments of officers in } \\
\text { the Tax and Distribution } \\
\text { Management Agency. }\end{array}$ & $\begin{array}{l}\text { Strengths, weaknesses, opportunities, } \\
\text { and threats in collecting retribution } \\
\text { and tax revenues }\end{array}$ \\
\hline 3 & 2 pearsons & $\begin{array}{l}\text { Officers from tax authorities in } \\
\text { Indonesia, Directorate General of Tax }\end{array}$ & Property tax valuation \\
\hline 4 & 6 persons & Lectures who teaches taxation & $\begin{array}{l}\text { Opportunities and threats in tax } \\
\text { collection }\end{array}$ \\
\hline 5 & 62 persons & Taxpayers & $\begin{array}{l}\text { Opinions about the amount of tax, } \\
\text { the method of payment; reasons for } \\
\text { paying taxes or not, and perceived } \\
\text { unwillingness. }\end{array}$ \\
\hline
\end{tabular}


1) Property tax, collected with official assessment system.

2) Tax revenues from hotel, restaurant, entertainments, and parking, collected with self-assessment system.

\subsection{Property Tax}

The property tax in this paper means that taxes are located in the cities and villages. The name of the law is PBB-P2 (Land and Urban and Rural Buildings Tax, namely Property Tax for Land and Building in City and Village). The summary of opportunities, threats, strengths, and weaknesses obtained from interviews with respondents are as follows:

\section{Opportunities (O)}

O1. The formal education at property magister is available in Medan City.

O2. There is an opportunity for cooperation between colleges and the appraiser association.

O3. There is an opportunity for cooperation among immigration, financial technology, licensing agency, National Land Agency, and the Central Bureau of Statistics.

O4. Technology development.

\section{Threats (T)}

T1. The society as taxpayers do not revise the data of the property as tax object, consequently the data of the property are not valid.

T2. There is distrust between the society and the government.

T3. The society is reluctant to pay property tax.

T4. The society does not understand the role of tax for the development.

T5. Property tax payables are large.

\section{Strengths (S)}

S1. Laws and regulations are adequate.

S2. The tax collection system is clear.

S3. There are enough funds to data validation, tax object revaluation, and other related programs.

S4. Taxpayers database are available.

\section{Weaknesses (W)}

W1. Not all property tax objects are validated and revaluated.

W2. The low discipline officers handle property tax object validation.

W3. Property tax object database are not updated and not yet integrated.

W4. There is no online payment.

W5. There are the lack of number and competency of officers in the tax object appraisers.

Focuss group discussions were conducted with officers in the Tax and Distribution Management Agency and lecturers to obtain strategies.

\section{TOWS Matrix}

Based on SWOT identification, a TOWS matric is developed and shown as below:

- S-O-propose strategies that could maximize the strengths by taking advan- 
tage of external opportunities.

- W-O-propose strategies to overcome weaknesses by taking advantage of external opportunities.

- S-T-propose strategies to enhance strengths through reducing the impact of external threat.

- $\mathrm{W}-\mathrm{T}$ - propose strategies aim at reducing internal weaknesses and avoiding external threats.

The summary of these strategies is presented in the following TOWS Matrics (Table 2):

The results of this SWOT analysis show the importance of integration of taxpayers databases with other agencies or units. This is in accordance with the statement that a detailed database can reduce the tax evasion and hence increase in tax revenue [2]. The strategies found are in line with the results of Savitri and Musfialdy [11] who said that services from tax officials and tax administration have a role in the relationship between taxpayer awareness, tax penalties, compliance fees and tax compliance.

\subsection{Tax Revenues}

These tax revenues are taxes from hotels, restaurants, entertainments, and parking. The summary of opportunities, threats, strengths, and weaknesses obtained from interviews with respondents are as follows:

Opportunities (O)

O1. Supported by government regulations.

O2. Technology development.

O3. Cooperate with other agencies, such as the licensing section, the immigration, the university, the tax authority, the police, the civil service police unit, the attorney, the Supreme Audit Agency (BPK), and the financial and development audit agency (BPKP).

Threats (T)

T1. There is collusion between the tax officers and taxpayers.

T2. The taxpayers tend to pay the tax revenues in a small amount.

T3. The taxpayers will avoid pay the tax revenues except there is a real advantage receipt.

T4. The taxpayers' comply is low.

\section{Strengths (S)}

S1. The tax collecting system is clear.

S2. The budget is available.

S3. The taxpayers' database is available.

S4. The tax officers have authority to audit the taxpayers to verify the taxpayers' complying for the tax payment and other purposes in according with the regional tax regulations.

Weaknesses (W)

W1. There is a limitation of technical supporting staffs, namely taxes auditors, tax investigators, and bailiffs. 
Table 2. TOWS Matrix for PPB-P2.

\section{Opportunities (O)}

O1. The formal education at property magister is available in Medan City.

$\mathrm{O} 2$. There is an opportunity for cooperation between colleges and the appraiser association.

O3. There is an opportunity for cooperation among immigration, financial technology, licensing agency, National Land Agency, and the Central Bureau of Statistics.

O4. Technology development.

\section{Threats (T)}

T1. The society as taxpayers do not revise the data of the property as tax object, consequently the data of the property are not valid.

T2. There is distrust between the society and the government.

T3. The society is reluctant to pay property tax.

T4. The society does not understand the role of tax for the development.

T5. Property tax payables are large.

\section{Strengths (S)}

S1. Laws and regulations are adequate.

S2. The tax collection system is clear. revaluation, and other related programs.

S4. Taxpayers database are available.
S3. There are enough funds to data validation, tax object

\section{Strategies SO}

1. Cooperate with the third parties in handling data validation and tax object revaluation with the available budgets $(\mathrm{S} 3, \mathrm{O} 2)$

2. Integrate taxpayers database with other agencies or units $(\mathrm{S} 4, \mathrm{O} 3)$.

\section{Strategies ST}

1. Conduct counseling and socialization of taxpayers about knowledge in tax. The taxpayers' discipline for the tax payment depends on the taxpayers' understanding about the tax, such as tax regulations and functions. This discipline can enforce the tax payments on the schedule (S1. S2, T2, T3, T4, T5).

2. Conduct "jeput bola" system for property tax, hold tax corner, and do property tax fair event (S3, T3, T4). Jeput bola system is the action to visit taxpayers in order helping them in paying taxes.

3. Increase the taxpayers complying by using gimmicks (S3, T3, T4, T5).

4. Give rewards to the taxpayers who paying taxes earlier (S3, T5).

5. Increase the public finance disclosure so that the public trusts increasing $(\mathrm{S} 1, \mathrm{~T} 2)$.

6. Delete the property tax fines in the special events (S3, T5).

7. Analyze the property tax payable to select the priority taxpayers who should be consulted (S4, T4).

8. Cooperate with related agency in order the taxpayers, especially with large tax payables, immediately paying the payables. If it is important, the taxpayers can be prohibited to go abroad. Some the related agencies are BPK (the Supreme Audit Board) and KPK (the Corruption Eradication Commission) (O3, T3).

\section{Strategies WT}

Strategies WO

1 . Obtain valid data by updating data by the officers (W1, W2,

1. Cooperate with colleges and an appraiser 1 . Obtain vald
association to make data validation, tax $\quad$ W3, W5, T1). object revaluation, and database updating (W1, W2, W3, W5, O2).

2. Cooperate with a financial technology provider to make application with newest technology to pay property tax easier (W4, O3). integrated.

W4. There is no online payment.

W5. There are the lack of number and competency of officers in the tax object appraisers.
3. Improve the human resources competencies especially for an appraiser in property tax by studying in master appraiser degree (W5, O2). 
W2. There is no ability to have the correct sales data.

W3. There is a weak supervisory function on revenue potential.

W4. The organization structure is not based on functions.

\subsection{TOWS Matrix}

Focuss group discussions were conducted with officers in the Tax and Distribution Management Agency and lecturers to obtain strategies. The summary of these strategies is presented in the following TOWS Matrics in Table 3 as follows:

Some of these strategies are in line with a findings of Bird and Zolt [12] which says that at any given level of administrative capacity, many things can be done with appropriate advanced technology so that tax administration officials can collect and evaluate information and use existing data more effectively.

According to Wang et al. [13], the increasing of revenues can be done by costumer-centric approach, reputation, channel management, estimating demand by big data, and fostering. This SWOT analysis has similar conditions with Wang et al. [13], such as paying attention to costumers, having enough and good data, and fostering.

This strategy is related to the management functions, planning, organizing, leading, and controlling. The planning is conducted by BPPRD and relates to data. If data are complete and update, the tax collection will be better and the sum of the tax can be estimated. Organizing is to arrange the organization structure by function in order to archive the organization purposes. Leading is the leader's direction to tax auditors in order to be more assertive in tax audits, improve tax knowledge, counsel and motivate taxpayers. Controlling relates to supervise to avoid tax fraud.

\section{Conclusions and Recommendations}

\subsection{Conclusions}

Based on TOWS strategies in Table 2 and Table 3, the main strategies are summarized as follows:

1) Data strategies are updating database, searching comparative data, fixing database, analyzing database, and sharing database to other related agencies.

2) Human resources strategies in BPPRD are improving knowledge and skill in accordance with their tasks and jobs, having assertive and honesty.

3) Taxpayers strategies are counseling and socialization, giving rewards and punishments, and providing convenience in paying taxes.

4) Coordinating and cooperating strategy with other related agencies are improved.

5) Controlling function strategy is increased especially for tax revenues potential.

\subsection{Recommendations}

There are some recommendations for BPPRD. BPPRD is suggested to state the 
Table 3. TOWS Matrix for the tax revenues.

\section{Opportunities (O)}

O1. Supported by government regulations.

O2. Technology development.

O3. Cooperate with other agencies, such as the licensing section, the immigration, the university, the tax authority, the police, the civil service police unit, the attorney, the Supreme Audit Agency (BPK), and the financial and development audit agency (BPKP).

\section{Strengths (S)}

S1. The tax collecting system is clear.

S2. The budget is available.

S3. The taxpayers' database is available.

S4. The tax officers have authority to audit the taxpayers to verify the taxpayers' complying for the tax payment and other purposes in according with the regional tax regulations.

\section{Weaknesses (W)}

$\mathrm{W} 1$. There is a limitation of technical supporting staffs, namely taxes auditors, tax investigators, and bailiffs.

W2. There is no ability to have the correct sales data.

W3. There is a weak supervisory function on revenue potential.

W4. The organization structure is not based on functions.

2. Educate the officers about technology used by the

\section{Strategies SO}

1. Increase the tax audits for the tax object to obtain the right number (S2, S4, O1). taxpayers in order the tax audits easier (S2, O2).

3. Simplify the registration procedures, reporting, and tax payments and improve the system information online (S1, S2, S3, S4, O2).

4. Use technology information system to detect the compliance with the taxpayers' obligations (S2, S3, O2).

5. Integrate the taxpayers' database with other agency database (S3, O3).

6. Enforce regulations and punish to the taxpayers that tax arrears $(\mathrm{S} 3, \mathrm{O} 1)$.

\section{Strategies WO}

1. Audit more assertive to the taxpayers' bookkeeping to find the correct data (W1, O1).

2. Improve the supervisory function of revenue potential through the efficiency of organizational structure (O2, W3).

3. Cooperate with the third agency in tax collection, such as the Supreme Audit Agency (BPK), the Corruption Eradication Commission (KPK), the Civil Service Police Unit (Polisi Pamong Praja), and Immigration unit (O2, W2).

4. Share data to other data provider institution such as tax authority in regional and center offices and licensing agency (W1, W2, O3).

5. Educate and train the tax officers to be able to cress check data and to find the critical points. This activity is also called finding "jangkar". For example, the hotel' revenues can be estimated by using toothpaste. The "jangkar" should be found to estimate revenues from restaurants and entertainments (O3, W2).

\section{Threats (T)}

T1. There is collusion between the tax officers and taxpayers.

T2. The taxpayers tend to pay the tax revenues in a small amount.

T3. The taxpayers will avoid pay the tax revenues except there is a real advantage receipt.

T4. The taxpayers' comply is low.

\section{Strategies ST}

1. Counsel and socialize the tax knowledge to the taxpayers because the discipline in tax payments is based on the taxpayers understanding level about the tax regulations. This discipline can reduce the postponement of tax payments (S1, S2, T2, T3, T4, T5).

2. Increase the compliance and awareness of taxpayers by persuasive-participative approaching (S3, T2, T3, T4).

3. Give reward to the taxpayers that early pay taxes (S2, S3, T4).

4. Increase the public financial openness so as to increase public trust $(\mathrm{S} 1, \mathrm{~T} 2)$.

\section{Strategies WT}

1. Get the comparative data to find the whole picture of the correct data in order to avoid the data fraud (T1, T2, T3, T4, W2).

2. Understand and study the taxpayers' process business, industry business cycles, and tax objects cycles to find the whole picture of the correct data in order to avoid the data fraud (T1, T2, T3, T4, W1, W2).

3. Develop the monitoring and evaluation system of the regional tax payments through tapping devices. This system is an online monitoring solution because it can record the data transaction from the cash register of the tax objects (T2, T3, T4, W3). 
policies for applying the strategies that finding in this paper. The recommendations expected implemented in the short term are as follow:

1) Putting on the tapping device for monitoring transactions data from the taxpayers' hotels, restaurants, entertainments, and parking.

2) Data validation and revaluations for property tax object.

3) Educating and training related to appraise property tax objects and to audit tax revenues from hotels, restaurants, entertainments, and parking as human resources strategies.

4) Counseling and socializations for the taxpayers and the society in Medan City's regions.

5) Improving coordinating and cooperating with other agencies, include data sharing.

\section{Acknowledgements}

The authors gratefully acknowledge that the present research is founded by Directorate of Research and Community Service Directorate General of Strengthening Research and Development Ministry of Research, Technology and Higher Education accordance with research funding agreement and community service for fiscal year 2018.

\section{Conflicts of Interest}

The authors declare no conflicts of interest regarding the publication of this paper.

\section{References}

[1] Ames, D., Hines, C.S. and Sankara, J. (2014) Are Earnings Quality Attributes Reflected in Financial Strength Ratings? American Journal of Business, 29, 293-311. https://doi.org/10.1108/AJB-12-2013-0073

[2] Ernest, O., Fikayo, F., Ogheneovo, E. and Ayodeji, J. (2015) Design and Development of an E-Taxation System. European Scientific Journal, 11.

[3] Fachrudin, K.A. (2018) Stock Price Analysis of Sustainable Foreign Investment Companies in Indonesia. IOP Conference Series. Earth and Environmental Sciences, $126,1-6$.

[4] McDonald, P. (2010) Teaching the Concept of Management: Perspectives from "Six Honest Serving Men”. Journal of Management and Organization, 16, 626-640.

[5] Loan, T.H. and McCluskey, W.J. (2012) Property Tax in Vietman: The Potential for Reform. Journal of Property Tax Assessment \& Admimistration, 7, 41-55.

[6] Babawale, G.K. (2013) Designing Appropriate Valuation Model for Sustainable Property Tax System in Developing Countries. International Journal of Law and Management, 55, 226-246. https://doi.org/10.1108/17542431311327646

[7] Sapiei, N.S. and Kasipillai, J. (2014) Tax Agents Perceptions of the Corporate Taxpayers' Compliance Costs under the Self-Assessment System. International Journal of Business and Management, 2, 92-109.

[8] Birskyte, L. (2013) Effects of Tax Auditing: Does the Deterrent Deter? Research Journal of Economics, Business and ICT, 8, 1-8, 53-76. 
[9] Gemmell, N. and Ratto, M. (2012) Behavioural Responses to Taxpayer Audits: Evidence from Random Taxpayer Inquiries. National Tax Journal, 65, 33-57. https://doi.org/10.17310/ntj.2012.1.02

[10] Nguyen, N.A., Doan, Q.H. and Tam, B.T. (2017) Tax Corruption and Private Sector Development in Vietnam. Journal of Tax Research, 15, 290-311.

[11] Savitri, E. and Musfialdy (2016) The Effect of Taxpayer Awareness, Tax Socialization, Tax Penalties, Compliance Cost at Taxpayer Compliance with Service Quality as Mediating Variable. Procedia-Social and Behavioral Sciences, 219, 682-687. https://doi.org/10.1016/j.sbspro.2016.05.051

[12] Bird, R.M. and Zolt, E.M. (2008) Technology and Taxation in Developing Countries : From Hand to Mouse. National Tax Journal, LXI, 791-821. https://doi.org/10.17310/ntj.2008.4S.02

[13] Wang, X.L., Heo, C.Y., Schwartz, Z., Legoherel, P. and Specklin, F. (2015) Revenue Management: Progress, Challenges, and Research Prospects. Journal of Travel \& Tourism Marketing, 32, 1-15. https://doi.org/10.1080/10548408.2015.1063798 